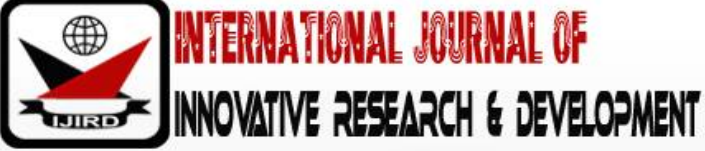

ISSN 2278 - 0211 (Online)

\section{Effect of Strategic Quality Management Practices on Organizational Performance of Mobile Telecommunications Companies in Rwanda: A Case of MTN Rwanda}

\author{
Sarah Mwende Wambua \\ Student, Jomo Kenyatta University of Agriculture and Technology, Kenya \\ Dr. Patrick Mulyungi \\ Student, Jomo Kenyatta University of Agriculture and Technology, Kenya
}

\begin{abstract}
:
This research sought to examine effect of strategic quality management practices on organizational performance of mobile telecommunication companies in Rwanda using MTN Rwanda as a case study. Specifically, the research sought to: examine effect of client focus in line with the firm's performance of the telecommunications organizations within Rwanda, examine the continuous improvement on organizational performance in telecommunications firms in Rwanda, examine top management commitment in the telecommunications firms in Rwanda and to analyze effect of ISO 9000 Practices with respect to the mobile telecommunications companies' performance in Rwanda. This research adopted a descriptive design. The target population of 150 was stratified into three strata: top management staff, middle management staff, and low-level management staff. Stratified sampling technique was used to reach to the entire population of the study. Stratified random sampling method brought out the aspect of accuracy and reliability to this study, because, each and every individual participated to this study. The study used both primary and secondary data collection methods. The researcher administered the questionnaire to each respondent. Quantitative data was collected and analyzed using SPSS and presented through percentage, mean, frequencies. Pearson correlation was used to assess if the relationship between the independent variables, and dependent variable which is organizational performance, was significant or not. From the findings all activities show that customer focus practices have been adopted in MTN Rwanda at large extent. All activities show that top management commitment practices have been adopted in the respective organizations at large extent. It was established that Quality management was embraced in the vision of the company to a large extent as shown by a mean of 4.02. All activities show that ISO 9000 practices have been adopted in the respective organizations at large extent with the mean ranging from 3.61 to 3.92. Therefore, this study recommends that telecommunication companies in Rwanda should consider adopting and implementing other quality management practices for example ISO 9000 and compares the benefits and the challenges of these quality management practices. This will provide a better platform of choosing the quality management practices that lead to improved organizational performance. The study also recommends that telecommunication companies in Rwanda need to level with the standards of highly successful firms globally in order to find out the quality management practices that the firms use in enhancing competitiveness. This will shed more light on the best quality management practices to adapt to increase organizational performance.
\end{abstract}

Keywords: Customer focus, organizational performance, mobile telecommunications companies

\section{Background}

Globally, Competition has forced many organizations to re-evaluate the competitive strategies that enable them to remain relevant and successful in the market (Agus, 2014). Customers' needs become increasingly difficult to meet. They demand for faster response, better value for money, products or services, more product varieties, expect lower prices, reliable delivery, and product integrity. Firms in the telecommunications companies, like firms in other sectors of the economy, need to devise strategies for effective competition. In spite of its important role in the economy, telecommunications companies are in turmoil due to sub-standard products, high energy costs, dilapidated transport infrastructure, and the dumping of cheap imports. As a result of these challenges the telecommunications companies has remained stagnant and lacks adaptability.

Parasuraman, Zeithaml and Berry (2018), notes that today's rapid advances in technology and shortened product life cycle, it is not likely that many companies may have expertise in all the areas necessary to produce competitive goods and services. As a consequence, an increasing number of companies are focusing their attention on both continuous improvement and radical innovation to enhance their competitiveness by using newly developed techniques and tools such as Just In Time (JIT) systems, Six Sigma, Lean Manufacturing, Enterprises Resources Planning (ERP), Supply Chain Management (SCM), and Strategic Quality Management (SQM) (Lee, 2012). 
Quality has become one of the most important drivers of the global competition today. Quality management practices incorporated overall organizational strategy, communicated to all employees and well implemented may have a positive impact on organizational performance (Sigei, 2014). The benefits of quality improvement cannot only be reflected on decreasing costs, but also on maximizing business profits. In terms of quality improvement, what really counts for a firm is not just cost minimization, but the effect that superior quality has on maximizing profits. Thus, a study on the relationship between strategic quality management practices and organizational performance is critical for organizations and researchers to better understand the effects of strategic quality management practices onto different levels of organizational performance. In order to accomplish the requirement of quality, organizations have to spend time and effort on the implementation of strategic quality management practices.

According to Parasuraman, Zeithaml, and Berry (2018), excellent service is a highly rewarding strategy because it results in more new customers, more business from existing customers, fewer lost customers, insulation from price competition and fewer mistakes in service provision that require re-performance of service. Further, profit impact of marketing strategy (PIMS) research has shown that companies that offer superior service are able to charge a premium price on their service offering while achieving higher than normal market share growth and profitability (Almanza \& Tomas, 2011). In the service companies which is characterized by intangibility of product offering, the key to organizational performance is to provide unique benefits that offset the higher prices. This according to Porter (2015), is the pursuit of the generic strategy of differentiation.

Competitive advantage has been a cornerstone concept in the field of strategic management since it explains what accounts for differences in performance among firms (Ceccagnoli, 2009). However, it has been argued that competitive advantage is a buzzword that is not well understood by academics, business executives and consultants (Amit and Zott, 2008). Further, understanding of what is competitive advantage and distinguishing this concept from organization performance remains a challenge for the discipline (Chinunda, 2011). Ansoff (2015) is the original scholar who attempts to define competitive advantage as the unique characteristics or specific properties of individual product markets which give a commercial entity a strong competitive position. The concept of competitive advantage is however attributed to Porter (2015) who introduced it to the world via his book by the same name. While Porter (2015) provides no clear definition of competitive advantage, he states that competitive advantage originates from the firm's ability to create superior value for its buyers and adds that superior value is obtained from offering lower prices than competitors for equivalent benefits or providing unique benefits that more than offset a higher price.

In the aggressive environment of today, it is essential for a business foundation to remain in front of rivalry and consistently fulfill clients" needs. Quality administrative practices have been generally actualized, although a few associations encounter incredible achievement, different activities have failed (Sigalas and Pekka-Economou, 2013). Numerous studies have begun scrutinizing the widespread utilization of value administration in all associations, and they assert that a portion of the quality administration practices are subject to the hierarchical setting, for example, industry, firm size and country

MTN Rwanda began its operations in 1998, starting out as an exclusive GSM (Global System Mobile Communication) network providing voice and SMS services. The portfolio has exponentially grown to include data, wireless internet, Mobile Money services, Enterprise solutions and other Value-Added Services. Technological innovation is vital to MTN's existence. We are committed to leading the delivery of a bold new digital world and through this, make our customers' lives a whole lot brighter. This mission has positioned us well for further growth into the future. MTN has the largest market and value share in the increasingly competitive telecommunications industry in Rwanda. It has close to 4 million subscribers and a network coverage of 99\%, with a footprint that is covered by 4G, 3.75G and EDGE (Enhanced Data GSM Environment) networks as well as an extensive fiber network. The company continues to invest heavily in infrastructure to expand its coverage and capacity across the country and has invested about 130 Billion Rwf over the last 5 years. MTN also acknowledges its responsibility towards its stakeholders to sustain long-term mutual value. In this regard, the company has established relationships with governments and community groups for partnerships that are geared towards improving the quality of service it offers to Rwandans through its Corporate Social Responsibility program, MTN Foundation. MTN Rwanda has continued to grow from being a generic telecommunication company known for basic telephony to a digital lifestyle-enabling, one-stop solutions shop that supports consumers through every moment and every stage of their life. Hence the big question on effects of strategic quality management on organizational performance by mobile telecommunication companies in Rwanda.

\subsection{Statement of the Problem}

Over the years, mobile telecommunication firms worldwide have been affected by day to day change in technology and more demand on new innovations, pressure from regulation authorities to adhere to the new rules and need to satisfy customers who demand more from innovative products. In this regard, SQM is being used for continuous improvement of process, involvement of suppliers, new training of staff to increase efficiency in satisfying Customer needs and achieve the desired organization performance. SQM tools and procedures may vary but the fundamental philosophy and concepts are equally important to industries from manufacturing as well as service (Zeithaml, 2010). Importance of services industry is significantly increasing in local and international economies.

MTN Rwanda face myriad challenges in provision of 2G, 3G and 4G services. The main challenges that affect MTN operations include spectrum or frequency availability, provision of quality services, demand for high speed connectivity by customers, competitive environment requiring constant innovation; sustainable revenue and profitable business growth (RURA Report, 2011). 
Strategic quality management particularly in the mobile telecommunications sector is an area that has seen limited research conducted particularly in Rwanda yet it is a viable source of organizational performance and it is hoped that this research elucidates its use and hopefully result in fewer exits in the Rwandan mobile telecommunication sector and increased profitability for all the operators. While there exist doubts on the actual reason for having one dominant player, there exists very few studies to show if SQM is a key driver of this dominance.

\subsection{Objectives of the study}

\subsubsection{General Objective}

The general objective of this study was to examine the effect of strategic quality management practices on organizational performance in the mobile telecommunication firms in Rwanda.

\subsubsection{Specific Objectives}

To assess the effect of customer focus on organizational performance in the mobile telecommunications firms within Rwanda.

2. Conceptual Framework

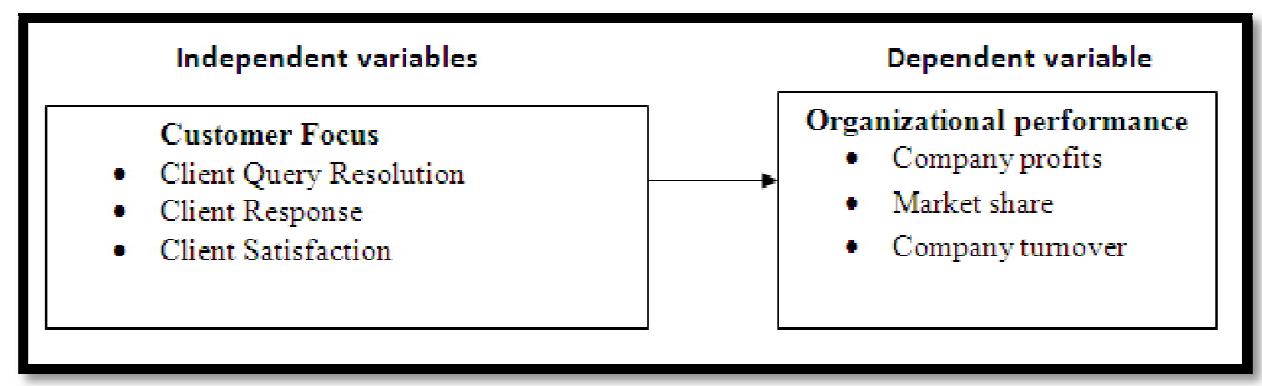

Figure 1: Conceptual Framework

\section{Target Population}

Cooper \& Schindler (2011) defines population as the total collection of elements about which the study makes some inferences. The population of this study consisted of Management team, middle management level managers and low-level managers of MTN Rwanda. The total population is 150 people.

\begin{tabular}{|c|c|}
\hline Departments for the Population & Total Population \\
\hline Board and executive Managers & 8 \\
\hline Senior managers & 30 \\
\hline Middle management & 32 \\
\hline Lower managers & 80 \\
\hline Total & 150 \\
\hline
\end{tabular}

Table 1: Target Population

Source: MTN Rwanda (2017)

\subsection{Sampling Procedure}

A total of 110 employees constituted the sample size for this study. The sample size was statistically calculated usingSlovins formula $\left(\mathrm{n}=\mathrm{N} / 1+\mathrm{N}(\mathrm{e})^{2}\right.$

Where;

$\mathrm{n}$ is the sample size,

$\mathrm{N}$ is the population size (150)

$\mathrm{e}$ is the desired level of precision (0.05)

$$
n=\frac{150}{1+150 \times 0.05 \times 0.05}=110
$$

\begin{tabular}{|c|c|c|}
\hline Departments for the Population & Total Population & Subsamples \\
\hline Board and executive Managers & 8 & 6 \\
\hline Senior managers & 30 & 22 \\
\hline Middle management & 32 & 24 \\
\hline Lower managers & 80 & 58 \\
\hline Total & 150 & 110 \\
\hline
\end{tabular}

Table 2: Sampling Frame 


\section{Research Findings and Discussion}

\subsection{Customer focus on Organizational Performance}

Based on research objective one, to assess the effect of customer focus on MTN Rwanda performance. Respondents opinion was based on a five-point Likert scale where respondents were supposed to indicate the level of agreement with different statements regarding the effect of customer focus on MTN Rwanda performance. The analysis is as shown in Table 3

\begin{tabular}{|c|c|c|c|c|c|c|c|}
\hline Statements & SA & A & U & D & SD & Mean & Std.dev \\
\hline $\begin{array}{c}\text { At MTN Rwanda there is already } \\
\text { existing mechanism for handling the } \\
\text { complaints of customers }\end{array}$ & 45.2 & 35.5 & 6.5 & 7.5 & 5.4 & 1.92 & 1.14 \\
\hline $\begin{array}{c}\text { At MTN Rwanda communication of } \\
\text { the expectations of customer is } \\
\text { always done }\end{array}$ & 30.1 & 34.4 & 19.4 & 7.5 & 8.6 & 2.30 & 1.22 \\
\hline $\begin{array}{c}\text { At MTN Rwanda employees are } \\
\text { always trained about customer care }\end{array}$ & 35.5 & 23.7 & 16.1 & 12.9 & 11.8 & 2.42 & 1.39 \\
\hline $\begin{array}{c}\text { MTN Rwanda regularly conducts } \\
\text { customer feedback surveys }\end{array}$ & 40.9 & 29.0 & 15.1 & 8.6 & 6.5 & 2.10 & 1.22 \\
\hline $\begin{array}{c}\text { MTN Rwanda carries out } \\
\text { benchmarking compared to other } \\
\text { telecommunication firm to measure } \\
\text { performance progress }\end{array}$ & 35.5 & 35.5 & 16.1 & 6.5 & 6.5 & 2.12 & 1.16 \\
\hline
\end{tabular}

Table 3: Respondents Views on Customer Focus on Organizational Performance

According to Table 3, 35.5\% of respondents agreed that at MTN Rwanda there is already existing mechanism for handling the complaints of customers, $45.2 \%$ respondents strongly agreed, $7.5 \%$ disagreed, $5.4 \%$ strongly disagreed, and $6.5 \%$ remained neutral to the statement. A mean of 1.92 and standard deviation of 1.14 was achieved.

Additionally, 34.4\% of respondents agreed that at MTN Rwanda communication of the expectations of customer is always done, $30.1 \%$ of respondents strongly agreed, $7.5 \%$ disagreed, $8.6 \%$ strongly disagreed while only $19.4 \%$ remained neutral. The mean was very high at 2.30 and confirmed the strong evidence of the fact; the standard deviation at 1.22.

The same Table 4.9 indicates that, $23.5 \%$ of respondents agreed that at MTN Rwanda employees are always trained about customer care, $35.5 \%$ respondents strongly agreed $12.9 \%$ disagreed, $8.2 \%$ strongly disagreed and only $16.1 \%$ were neutral. The mean was very high at 2.42 and confirmed the strong evidence of the fact; the standard deviation at 1.39.

Among the contacted respondents, $29 \%$ of respondents agreed that MTN Rwanda regularly conducts customer feedback surveys, $40.9 \%$ of respondents strongly agreed, $8.6 \%$ disagreed, $6.5 \%$ strongly disagreed while $15.1 \%$ were indifferent with the findings. The mean was very high at 2.10 and confirmed the strong evidence of the fact; the standard deviation at 1.22 .

Lastly, among the contacted respondents, 35.5\% respondents agreed that MTN Rwanda carries out benchmarking compared to other telecommunication firm to measure performance progress, $35.5 \%$ respondents strongly agreed, $6.5 \%$ disagreed, $6.5 \%$ strongly disagreed and $16.1 \%$ remained indifferent, the mean was very high at 2.12 and confirmed the strong evidence of the fact; the standard deviation at 1.16 .

In conclusion the findings shown in Table 4.9 indicate that at MTN Rwanda there is already existing mechanism for handling the complaints of customers as shown by majority respondents who agreed, at MTN Rwanda communication of the expectations of customer is always done, at MTN Rwanda employees are always trained about customer care and MTN Rwanda regularly conducts customer feedback surveys.

\subsection{Regression Analysis}

Model summary is a summery that describes how far the in dependent variables explain the dependent variables that mean the greater $\mathrm{R}$ value has the great number the greater independent variables explain with dependent variable. In order to test the research hypotheses, a standard multiple regression analysis was conducted using organizational performance the dependent variable, and the four investigations determine effect of customer focus, continuous improvement, top management commitment, ISO 9000 practices of the organizational performance.

Tables 4, 5 and 6 present the regression results. From the model summary the adjusted $\mathrm{R}^{2}$ was 0.757 indicating that a combination of customer focus, continuous improvement, top management commitment, ISO 9000 practices explained $75.7 \%$ of the variation in the organizational performance.

\begin{tabular}{|c|c|c|c|c|}
\hline Model & R & R Square & Adjusted R Square & Std. Error of the Estimate \\
\hline 1 & $.887^{\mathrm{a}}$ & .764 & .757 & .2104 \\
\hline
\end{tabular}

Table 4: Model's Goodness of Fit Statistics

a. Predictors: (Constant), Customer Focus, Continuous Improvement, Top

Management Commitment, ISO 9000 Practices 
The significance value shown in Table 5 is 0.000 which is less than 0.05 thus the model is statistically significance in predicting how strategic quality management practices influence organizational performance of mobile telecommunication companies in Rwanda. The F critical at 5\% level of significance was 35.037. Since F calculated is greater than the $\mathrm{F}$ critical (value $=39.475$ ), this shows that the overall model was significant.

\begin{tabular}{|c|c|c|c|c|c|c|}
\hline \multicolumn{2}{|c|}{ Model } & Sum of Squares & df & Mean Square & F & Sig. \\
\hline \multirow{3}{*}{1} & Regression & 120.450 & 5 & 120.450 & 35.037 & $.000^{\mathrm{b}}$ \\
\cline { 2 - 7 } & Residual & 32.659 & 32 & .573 & & \\
\cline { 2 - 7 } & Total & 153.109 & 37 & & & \\
\hline
\end{tabular}

Table: 5 ANOVAA

a. Dependent Variable: Organizational Performance

b. Predictors: (Constant), Customer Focus, Continuous Improvement, Top

Management Commitment, ISO 9000 Practices

Table 6 presents the regression results on how Customer focus, continuous improvement, top management commitment, ISO 9000 practices determines organizational performance of mobile telecommunication companies in Rwanda.

\begin{tabular}{|c|c|c|c|c|c|c|}
\hline Model & & \multicolumn{2}{|c|}{$\begin{array}{c}\text { Unstandardized } \\
\text { Coefficients }\end{array}$} & $\begin{array}{c}\text { Standardized } \\
\text { Coefficients }\end{array}$ & t & Sig. \\
\hline & & B & Std. Error & Beta & & \\
\hline 1 & (Constant) & 1.033 & .504 & & 2.049 & .041 \\
\hline & Customer focus & .078 & .031 & .130 & 2.485 & .013 \\
\hline & Continuous improvement & .099 & .047 & .130 & 2.124 & .034 \\
\hline & $\begin{array}{c}\text { Top management } \\
\text { commitment }\end{array}$ & .085 & .044 & .117 & 1.920 & .056 \\
\hline & ISO 9000 Practices & .233 & .053 & .245 & 4.397 & .000 \\
\hline
\end{tabular}

Table 5: Coefficient Results

The multiple regression equation was that: $Y=\alpha+\beta 1 X_{1}+\beta_{2} X_{2}+\beta_{3} X_{3}+\beta_{4} X_{4}+\mu$

and the multiple regression equation became:

$\mathrm{Y}=1.033+0.078 \mathrm{X}_{1}+0.099 \mathrm{X}_{2}+.085 \mathrm{X}_{3}+0.233 \mathrm{X}_{4}$.

Table 6 presents the beta coefficients of all independent variables versus performance at MTN Rwanda. As can be observed from Table 6, customer focus (X1) had a coefficient of 0.078 which is greater than zero. The t statics is 2.485 which has a p-value of 0.013 which is less than 0.05 implies that the coefficient of X1 is significant at 0.05 level of significance. This shows that customer focus has a significant positive influence on Performance of MTN Rwanda. The coefficient of continuous improvement (X2) was 0.099 which was greater than zero. The t statistic of this coefficient is 2.124 with a $p$ value of 0.034 which is less than 0.05 . This implies that the coefficient 0.099 is significant. Since the coefficient of X2 is significant, it shows that continuous improvement making has a significant influence on performance of MTN Rwanda.

Table 6 also shows that top management commitment (X3) had a coefficient of 0.085 which is greater than zero. The $t$ statics is 1.920 which has a p-value of 0.056 which is greater than 0.05 implies that the coefficient of X3 is insignificant at 0.05 level of significance. This shows that top management commitment has an insignificant positive influence on Performance of MTN Rwanda. Table 6 further shows that ISO 9000 Practices (X4) had a coefficient of 0.233 with a t static of 4.397 which has a p-value of 0.000 which is less than 0.05 . This implies that the coefficient of X4 is significant at 0.05 level of significance. This shows that ISO 9000 Practices has a significant positive influence on Performance of MTN Rwanda.

\section{Conclusions}

The successful implementation of quality programs depends on workforce. If mobile telecommunications companies in Rwanda would have more trained, involved and empowered employees it is more likely to realize benefits of implementation of quality management techniques. The findings of research study suggest that management of manufacturing industry should be more involved in quality improvement programs.

The mobile telecommunications companies in Rwanda is accepting the importance of quality management practices which are getting popular in this industry. But the pace of adopting new practices and their successful implementation is still lagging behind the advanced countries. The firms in mobile telecommunications companies in Rwanda which are customer focused and were working on continuous improvement by following benchmarking practices were realizing better organizational performance. The success of quality management practices in delivering desired organizational performance is strongly influenced by the effective role of leadership.

\subsection{Recommendation}

In view of the data analysis conducted and inferential statistics the researcher would therefore suggest that continuous improvement practices have significant influence on organizational performance hence the need for 
organizations to consider use of continuous improvement practices to be able to focus on the cultural issues that may impact on the organization delivery. The study therefore recommended the state corporations to consider adoption of good continuous improvement practices and review of policies related organizational culture from time to time.

The study findings also confirmed that strategic leadership practice has significant influence on implementation of quality management systems and therefore the study recommended that the top management ensures resource availability to enable people meet the targets and objectives for both functional and as organization as a whole. Further, the leadership should invest in good financial management policies to ensure prudence use of resources. The study recommends that telecommunications companies in Rwanda should adopt and implement alternative QMP strategies e.g. ISO 9000 for purposes of comparison and selecting the best practices for improved operational performance. Mobile telecommunication companies in Rwanda ought to benchmark themselves against the best performing firms globally in an effort to enhance competitiveness

\subsection{Areas for Further Research}

Future research may employ different research methods to investigate more systematically and ascertain the causal relationships implicit assumed in this study. Future research should unfold further dimensions of SQM and examines the impact of each on various dimensions of organization performance, as this would be fruitful in testing this causal relationship more deeply. Future researchers must work upon all the dimensions of quality management and they must ensure that no dimension would be shadowed by the other item.

\section{References}

i. Agus, A. (2014). "Total Quality Managements a Focus for Improving Overall Service Performance and Customer satisfaction: an empirical study on a public service Sector in Malaysia", Total Quality Management and Business Excellence, 15(5), 615-628.

ii. Al-Dararkah, M., \& Shebley, T. (2012). Quality in Contemporary Organizations. Amman, Jordan: Dar Alsafa Publishing and Distribution.

iii. Allen, R. S., \& Helms, M. M. (2016). Linking Strategic Practices and Organizational Performance to Porter's Generic Strategies. Business Process Management Journal, 12(4), 433 - 454

iv. Almanza, R. M., \& Tomas, C. M. (2011). Challenges and perspectives in using PIMS methodology to explain the success of the marketing strategy in businesses. Contaduria Administration, 234(2), 79-99.

v. Amelia, S. \& Carr, H. K. (2017). Communication methods, information sharing, supplier development and performance: An empirical study of their relationships", International Journal of Operations \& Production Management, 27(4), 346 - 370.

vi. Amit, R., \&Zott, C. (2008). The Fit Between Product Market Strategy and Business

vii. Model: Implications for Firm Performance.Journal of Strategic Management, 29(1), 1-26.

viii. Ansoff, H. I. (2015). Corporate Strategy. New York, NY: McGraw-Hill.

ix. Asli-Aksoy, N. O. (2011). "Supplier selection and performance evaluation in just-in time production environments", Expert Systems with Applications, 38(2011), 6351-6359.

x. Bakan, I., \& Dogan, I. F. (2012). Competitiveness of Industries Based on Porters

xi. Diamond Model: An Empirical Study. IJJRAS, 11(3), 441-455.

xii. Cakmak, P. I., \& Tas, E. (2012). Strategic Planning Practices of Contractor Firms in

xiii. Turkey. 8th International Strategic Management Conference (pp. 40-46). Procedia - Social and Behavioral Sciences.

xiv. Ceccagnoli, M. (2009). Appropriability, preemption, and firm performance. Strategic

xv. Management Journal, 30(1), 81-98. Chinunda, E. D. (2011). Practical Insights on Customer Service: An African Perspective.

xvi. London, UK: Adonis \& Abbey Publishers Ltd.

xvii. Clarkson, M. (2015). A Stakeholder Framework for Analyzing and Evaluating Corporate Social Performance", Academy of Management Review, 20(1), 92-117.

xviii. Crosby, P. B. (2009). Quality Is Free. New York, NY: McGraw-Hill.

xix. Crow, K. (2010). Customer-Focused Development with QFD. California: NPD Solutions.

xx. Cooper, P. R. \& Schindler, P.S. (2011). Business research methods. New York: Wiley.

xxi. Deming, W. E. (2012). Quality, Productivity, and Competitive Position. Massachusetts Institute of Technology. Cambridge, MA: Center for Advanced Engineering Study.

xxii. Dholakia, R., Zhao, M., \& Dholakia, N. (2015). Multichannel Retailing: A Case Study of

xxiii. Early Experiences. Journal of Interactive Marketing, 19(2), 63-74.

xxiv. Freeman, R. (2013). Strategic Management: A stakeholder approach, Advances in Strategic management, 1(3), 3160 .

xxv. Goetsch, D. L., \& Davis, S. B. (2010). Quality Management Organizational Excellence:

xxvi. Introduction to Total Quality Management 6th Edn. Saddle River: Pearson.

xxvii. Goetsch, D. L., \& Davis, S. B. (2013). Quality Management for Organizational

xxviii. Excellence: Introduction to Total Quality. New Jersey: Pearson.

xxix. Jain, P. (2013). Telecommunication Service Quality Assessment: A Comparative Study of Bharat Sanchar Nigam Limited and Reliance Communications. Acia-Pacific Journal of Management, 9(1), 99-106.

xxx. Javed, S. (2015). Impact of Top Management Commitment on Quality Management, +International Journal of Scientific and Research Publications, 5(8), 2250-3153. 
xxxi. Jensen, M. C., \& Meckling, W. (2016). "Theory of the Firm: Managerial Behavior,

xxxii. Agency Costs and Ownership Structure", Journal of Financial Economics, 3(4), 305-360.

xxxiii. Khairul-Anuar, M. N. (2013). The Impact of Total Quality Management (TQM) on the Hospital's Performance: An Empirical Research, International Journal of Services and Operations Management, 15(4), 482-506.

xxxiv. Kibachia, J. (2014). A survey of risk factors in the strategic planning process of

xxxv. parastatals in Kenya. European Journal of Business and Innovation Research Vol.2, No.3, pp. 51-67.

xxxvi. Kombo, D.K., \& Tromp, D.L.A. (2009). Proposal and thesis writing: An introduction.

xxxvii. Nairobi. Paulines Publications Arica.

xxxviii. Kothari, C. (2014). Research methodology: Methods and Techniques. (3rd ed.). New Delhi: New Age International

xxxix. Kottler, P., \& Keller, K. K. (2012). Designing and Managing Services. New York: Free Press.

xl. Kumar, D. A., \& Balakrishnan, V. (2011). "A Study on ISO 9001 Quality Management

xli. System Certifications-Reasons behind the Failure of ISO Certified Organizations", Global Journal of Management and Business Research, 11(9), 43-50.

xlii. Lee, M. Y., Kim, Y. K., \& Knight, D. (2018). Brand Analysis of a US Global Brand in Comparison with Domestic Brands in Mexico, Korea and Japan. Journal of Product and Brand Management, 17(3), 163-174.

xliii. Macinati, M. S. (2008). "The relationship between quality management systems and organizational performance in the Italian National Health Service," Health Policy, vol. 85, no. 2, pp. 228-241.

xliv. Markides, C. (2010). Cross talk: strategy and management: constantinos markides discusses strategic innovation, an interview by Peter Mang. European Management Journal, 18(4), 357-366.

xlv. Matata, D. J., \& Wafula, M. K. (2015). “Effects of Quality Management Systems on

xlvi. Performance of Kenya Ports Authority”, International Journal of Scientific and Research Publications, 5(5), 1-13.

xlvii. Mugenda, O. M., \& Mugenda, A. G. (2010). Research methods: Quantitative and qualitative approaches. NairobiKenya: Acts Press.

xlviii. Mugenda, O.M., \& Mugenda, A.G. (2013). Research methods. Nairobi: McMillan Publishers.

xlix. Neslin, S. A., \& Shankar, V. (2017). Key Issues in Multi-Channel Customer

l. Management: Current Knowledge and Future Directions. The Journal of Interactive Marketing, 21(3), 30-44.

li. Njenga, E. W. \& Kidombo, H. (2017). Influence of Implementation of Quality

lii. Management System on Operational Performance of Technical Training Institutions in Meru County: A Case of Nkabune Technical Training Institute, Kenya, International Academic Journal of Information Sciences and Project Management, 2(1), 370-389.

liii. Oakland, J. S. (2016). Oakland on Quality Management. Amazon: Routledge.

liv. Orodho, A. J. (2013). Essentials of educational and social science research method.

lv. Nairobi: Masola Publishers.

lvi. Parasuraman, A., Zeithaml, V. A., \& Berry, L. L. (2018). SERVQUAL: A Multiple-Item scale for Measuring Consumer Perceptions of Service Quality. Journal of Retailing, 64(1), 12-40.

lvii. Porter, M. E. (2015). Competitive advantage: Creating and sustaining superior performance. New York, NY: Free Press.

lviii. Rahhal, W. (2015). The Effects of Service Quality Dimensions on Customer Satisfaction:

lix. An Empirical Investigation in Syrian Mobile Telecommunication Services. International Journal of Business and Management Invention, 4(5), 81 - 89.

lx. Roberta, S., \& Russell, B. W. (2000-2016). Operations and Supply Chain Management,

lxi. 8th Edn. New Jersey: John Wiley \& Sons, Inc.

lxii. Rogers, E. M. (2013). Diffusion of Innovations (3rd ed.). New York, NY: The Free Press.

lxiii. Saunders, M., Lewis, P., \& Thornhill, A. (2009). Research methods for business students.

lxiv. (5th Ed.). London: Prentice Hall.

lxv. Serakan, U. (2013). Research Methods for Business: A skill Building Approach (4th ed.).

lxvi. New York: John Wiley \& Sons Publishers.

lxvii. Shukla, M. K. \& Agrawal, P. C. (2012) The Structural Relationships between TQM

lxviii. Factors and Organizational Performance in Indian Automobile Sectors International Journal of Engineering and Innova tive Technology (IJEIT). 1 (3) pp 119-121

lxix. Sigalas, C., \& Pekka-Economou, V. (2013). Revisiting the concept of competitive advantage: problems and fallacies arising from its conceptualization. Journal of Strategy and Management, 6(1), 61-80.

lxx. Sigei, C. K. (2014). Total quality management and performance of Multinational

lxxi. Pharmaceutical firms in Nairobi, Kenya. Unpublished MBA Thesis, Nairobi: University of Nairobi.

lxxii. Sturman, M. C. (2014). The Differential Effects of the Quality and Quantity, Cornell

lxxiii. Hospitality Quarterly, 55(4), 365-375.

lxxiv. Suhong-Li, B. R. (2016). The Impact of Supply Chain Management Practices on

lxxv. Competitive Advantage and Organizational Performance, The international journal of management science, 48(10), 1301-1313.

lxxvi. Talib, F. (2010). “The Relationship between Total Quality Management and Quality

lxxvii. Performance in the Service Industry: A Theoretical Model", International Journal of Business, Management and Social Sciences. 1(1), 113-128. 
lxxviii. Talib, F., Rahman, Z. and Qureshi, M.N. (2010). The relationship between total quality management and quality performance in the service industry: a theoretical model. International Journal of Business, Management and Social Sciences Vol. 1, No. 1, pp. 113-128

lxxix. Tomatzky, L. G., \& Klein, K. J. (2012). Innovation Characteristics and Innovation Adoption Implementation: A MetaAnalysis of Findings. IEEE Transactions of Engineering Management, 29(1), 28-43.

lxxx. Van der Wal, R. W., Pampallis, A., \& Bond, C. (2012). Service quality in a cellular telecommunications company: A South African experience. Managing Service Quality, 12(5), 323-335.

lxxxi. Wahid, A. R., Corner, J., \& Tan, P.-L. (2011). ISO 9000 Maintenance in Service

lxxxii. Organizations: Tales from Two Companies, International Journal of Quality \& Reliability Management, 28(7), 735757.

lxxxiii. Wahid, R. A. (2009). Critical Success Factors and Problems in ISO 9000 Maintenance".

lxxxiv. International Journal of Quality and Reliability Management, 26(9), 881-893.

lxxxv. Wanderi, E.N. (2015). Factors Influencing Implementation of Total Quality Management in Construction Companies in Rwanda: A Case of Fair Construction Company. Unpublished Project of Jomo Kenyatta University.

lxxxvi. Wang, Y., \& Lo, H.-P. (2012). Service quality, customer satisfaction and behavior intentions. Info, 4(6), 50-60.

lxxxvii. Zeithmal, A. (2010). Service quality, profitability and the economic worth of customers:

lxxxviii. What we know and what we need to learn.Journal of the Academy of Marketing Science, 28(1), 67-85.

lxxxix. Zikmund, G.W., Babin, B.J., Carr, C.J., \& Griffin, M. (2010). Business research methods. (8th ed.). South-Western, Cengage Learning.

xc. Zipporah, K. M. (2016). "Quality Management Systems and Organizational Performance:

xci. A Theoretical Review in Kenya's Public Sector Organizations", Science Journal of Business and Management. 4(5), 150- 155 . 